\title{
THE SYMBOLIC MEANING OF COPERNICUS' SEAL
}

\section{By Staniskaw Mossakowski*}

The personal letters of Nicolaus Copernicus (1473-1543) bear the stamp of an intaglio as the private seal of the great astronomer (fig. 1). ${ }^{1}$ The dimensions of the object are so slight $(12: 10 \mathrm{~mm})$ that it is quite possible he wore it set in a signet-ring; the traces of a wide setting prove it actually had one. In spite of the small size of the intaglio and the obliteration of many details, due to pressing it against paper and not directly in wax, a deeply engraved image is quite legible. It represents Apollo playing a lyre, well inscribed within the oval shape of the gem. The young god, covered only with a narrow chlamys, is leaning back and treads lightly, as though on tiptoe, holding the lyre in front of himself.

Latona's almost naked son with the lyre is not represented here as Apollo Kitharodos who according to an old tradition, coming down to the fifth century B.C., ought to play the kithara and be dressed in a long chiton and a coat. But the representations of a naked Apollo with a lyre were not foreign to Greek art and had already appeared in the archaic period. As to the iconographic type, a close parallel can be found in a sardonyx intaglio preserved in Florence and described by Furtwängler as Hellenistic. ${ }^{2}$ In this work, although completely different in style, the figure is also leaning back and has the chlamys thrown over the shoulder in the same manner. Other similarities are the way the instrument is held and the figure's treading on tiptoe. A survey of the ancient gems, published by Furtwängler, allows us to state that the ancient origin of Copernicus' intaglio cannot be denied. ${ }^{3}$

The seal used by the great astronomer has been noticed by many scholars, but in the area of interpretation only general opinions were put forward. ${ }^{4}$

*This note is based on a somewhat longer paper read at the Copernican Symposium in Lublin Catholic University, Feb. 18, 1972, to be published in Polish in "Rocznik Historii Sztuki PAN," vol. 10. I am deeply grateful to Prof. Edward Rosen, City University of New York, for several valuable references, criticisms, and editorial suggestions.

'It appears on all of Copernicus' letters from 1524 on. The earliest known letter, dated Oct. 22, 1518, was lost during World War II. In a photocopy of its recto side no traces of a seal are visible and the literature about it does not mention the existence of such a seal. For this information I owe thanks to Jerzy Drewnowski, of the Copernicus Research Studio of the Polish Academy of Science in Warsaw, who kindly drew my attention to Copernicus' seal.

${ }^{2}$ A. Furtwängler, Die antiken Gemmen (Leipzig-Berlin, 1900), I, pl.XXXIX-4; II, 186, and III, 348.

${ }^{3}$ Furtwängler, op. cit., passim; G. Lippold, Gemmen und Kameen des Altertums und der Neuzeit (Stuttgart, s.a.), passim; Antike Gemmen in deutschen Sammlungen (Munich, 1968-70), passim; G. M. A. Richter, Engraved Gems of the Romans (New York, 1971), passim.

${ }^{4}$ E.g.: L. Prowe, Nicolaus Coppernicus, Neudruck der Ausgabe 1883-1884 (Osnabruck, 1967), I-1, 48; I-2, 378, and II, 470, 473; Ludwik Antoni Birkenmajer, Mikotaj Kopernik (Cracow, 1900), 30; J. Wasiutyński, Kopernik twórca nowego nieba (Warsaw, 


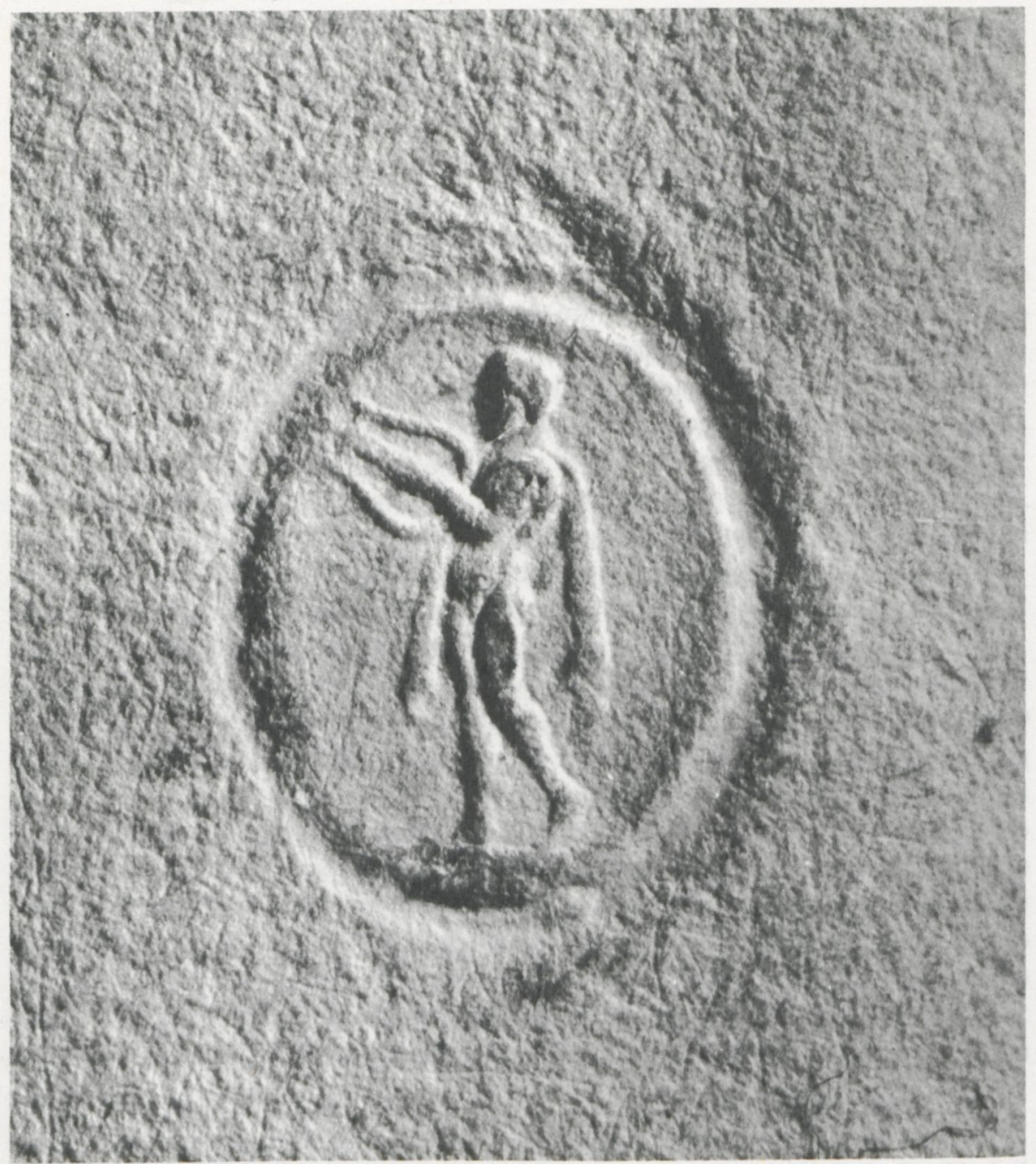

Figure 1. A stamp of the Copernicus' seal (Czartoryski Library in Cracow, MS 1596, p.557). Photo S. Lopatka.

The aim of the present paper is to determine why Copernicus made a personal emblem of the image of that particular ancient god.

It is noteworthy that unlike his brother Andreas (d.1518), who was also a canon of Varmia, Nicolaus Copernicus did not use a coat of arms of the related von Allen family, ${ }^{5}$ nor did he invent a special cachet for himself, as, e.g., Conrad Celtis did. Copernicus' choice of an ancient god as a personal

1938), 192, 385-86; H. Barycz, Mikotaj Kopernik wielki uczony Odrodzenia (Warsaw, 1953), 28; B. Leśnodorski, "Kopernik - humanista," Mikołaj Kopernik. Szkice monograficzne, ed. J. Hurwic (Warsaw, 1965), 244; S. K. Kuczyński, “Pieczeć Mikołaja Kopernika," Mówia wieki, 13 (Sept. 1970), 12-13, and "Mikołaja Kopernika sygnet z Apollem," Biuletyn numizmatyczny, 62 (April 1971), 69-71.

${ }^{5} \mathrm{Cf}$. Prowe, op.cit., II, 270 and 473. 
emblem may have been in conformity with a widespread practice among learned humanists of that time. Girolamo Fracastoro (1478-1553), an eminent poet, man of letters, distinguished physician and astronomer at Padua, chose as his device an image of an altar dedicated to Aesculapius, Apollo, and Minerva ${ }^{6}$ On a tombstone, in several portraits, and on a signet-ring of the great Erasmus of Rotterdam one can find an image of the ancient god Terminus. It might be useful to recall that this Roman god of boundaries was taken by Erasmus as his device after Alexander Stewart, his pupil and friend, in 1509 gave him an ancient gem with an image which was interpreted as that of Terminus. $^{7}$ In the correspondence of the Varmian canons, moreover, there appeared a seal stamp in 1520 with an image of Mercury. ${ }^{8}$ This could have served as an immediate source of inspiration for the choice on the part of the astronomer and Varmian canon, unless of course Copernicus began to use his intaglio seal before 1520 .

The choice of an ancient or pseudo-ancient work of art as a personal seal might be better understood in the light of Copernicus' thorough humanistic education, his translation of the Greek letters of Theophylactus Simocatta into Latin, and his deep admiration for antiquity. ${ }^{9}$ The choice of Apollo, patron of artists, philosophers, and physicians, might also be read as a simple declaration, on the part of the Varmian scientist and physician, of membership in the humanistic respublica litteraria. ${ }^{10}$ But a taste for ambiguity, so characteristic of many humanists as well as of Copernicus, ${ }^{11}$ and his tendency to cover the actual meaning of a statement "... in a Pythagorean way," ${ }^{12}$ encourage the search for a deeper symbolic meaning of this intaglio.

Such an inquiry is justified also by the fact that the Greek and Roman god Apollo occupied a special place in the astronomy and astrology of antiquity as well as of mediaeval and renaissance times. Called "Phoibos" (radiant) by Homer, as early as the fifth century B.C., Apollo was identified with the planetary god Helios. This identification spread in Hellenistic times and during the Roman Empire when under Asiatic influence solar cults begin to dominate religious thought. Apollo-Phoebus as a synonym of a Sun-god ap-

${ }^{6} \mathrm{~F}$. Saxl, "Pagan Sacrifice in the Italian Renaissance," Journal of the Warburg Institute, 2 (1939), 357, and pl. 60c.

${ }^{7}$ E. Wind, “Aenigma Termini," Journal of the Warburg Institute, 1 (1937-38), 6669; J. Bialostocki, “Rembrandt's 'Terminus'," Wallraf Richartz Jahrbuch, 28 (1966), 55, and E. Panofsky, "Erasmus and the Visual Arts," Journal of the Warburg and Courtauld Institutes, 32 (1969), 215, pl.23.

${ }^{8}$ This information, kindly given me by Jerzy Drewnowski, will appear in Copernicus' Opera omnia, III. Vol.I was published in 1972 (Warsaw and London).

${ }^{9}$ Cf. e.g.: L. A. Birkenmajer, op.cit., 99-127; E. Rosen, “Copernicus' Quotation from Sophocles," Didascaliae. Studies in Honor of A. M. Albareda, ed. S. Prete (New York, 1961), 369-79, and E. Rosen, Three Copernican Treatises, 3rd ed. (New York, 1971), 324-26, 335-38.

${ }^{10}$ Cf. opinions by Prowe, op.cit., I-2, 378; Wasiutyński, op.cit., 386; Barycz, op.cit., 28; Leśnodorski, op.cit., 244.

${ }^{11}$ Cf. L. A. Birkenmajer, op.cit., 105-06, 120.

${ }^{12}$ Nicolaus Copernicus, "Preface to De revolutionibus," trans. J. F. Dobson, Royal Astronomical Society Occasional Notes, 2, 10 (Londn, 1947), 3; Gorg Joachim Rheticus, "Narratio prima," Three Copernican Treatises, trans. E. Rosen, ed. cit., 193. 
peared frequently in classical Latin literature, for example, in Cicero, Ovid, and Horace. On the other hand, the sun as a source of light and indicator of time - the day and the year-played an important role in ancient cosmology. In the geocentric conception of the world it was taken for an errant star, a planet, and placed halfway between the earth and the starry sky. Cicero in Somnium Scipionis wrote: “... almost midway of the distance is the Sun, the lord, chief, and ruler of the other lights, the mind and guiding principle of the universe, of such magnitude that he reveals and fills all things with his light." ${ }^{\prime 3}$ And Pliny the Elder called it: “ $\ldots$ the ruler not only of the seasons and of the lands, but even of the stars themselves and of the heaven."14

These statements are clearer when viewed in the light of another ancient cosmological concept, the Pythagorean theory of the Harmony of the Universe. ${ }^{15}$ According to this theory, taken up by Plato and made popular by the Stoics, the celestial spheres in their constant motions produce certain clearly definable sounds which constitute a full and perfect harmony, although inaudible to human beings. Different authors gave various explanations of the origin of this music of the spheres. The most popular theory, propounded among others by Macrobius, was that it is a song or a play of nine Muses, who at the same time become the movers of the spheres. ${ }^{16}$ Apollo-Phoebus, i.e., the Sun as a leader of the Muses (Musagetes, Dux Musarum) was thought to be the ruler of the planetary spheres, and the seven tones of his musical instrument, represented by the seven-corded ancient Greek lyre, were held to be the parallel of the sounds of the seven spheres from which the world harmony arose.

This fascinating myth of pagan antiquity, not unknown even in the Christian Middle Ages, was fully revived in the age of Humanism and the Renaissance. Constantly quoted by writers and scientists, it was illustrated or alluded to by many artists, musicians, and painters as well. Franchino Gafurio, the famous Renaissance musical theorist, a friend of Leonardo, made it the subject of the frontispiece in his Practica musicae (Milan, 1496). ${ }^{17}$ This woodcut (fig. 2) attempts to demonstrate: "That the Muses, the Planets, the

${ }^{13}$ Cicero, De re publica, VI, 17. Trans. C. Walker Keyes in the Loeb Classical Library (London, 1943), 271.

${ }^{14}$ Plinius, Naturalis historia, II, 12-13. Trans. H. Rackham in the Loeb Classical Library (London, 1938), II, 179.

${ }^{15}$ See literature quoted by H. Hüschen, "Harmonie," in Die Musik in Geschichte und Gegenwart, 5 (1956), cols. 1588-1614; Z. Ameisenowa, "Some neglected representations of the Harmony of the Universe," Essays in Honor of Hans Tietze (Paris, 1958), 349-64; and K. Meyer-Baer, Music of the Spheres and the Dance of Death (Princeton, 1970), 3-216.

${ }^{16}$ Macrobius, Commentarii in Somnium Scipionis, II, 3, 1-5. For the texts of the other ancient authors on the theme: W. Gundel, Sterne und Sternbilder im Glauben des Altertums (Leipzig, 1922), 97; and Meyer-Baer, op.cit., 27, 30-32; M. T. D'Alverny, "Les Muses et les sphères célestes," Classical, Mediaeval and Renaissance Studies in Honor of Berthold Louis Ullman (Rome, 1964), II, 7-19.

${ }^{17}$ In Gafurio's De harmonia musicorum instrumentorum (Milan, 1518), a later edition of the Practica with commentary, this woodcut is printed on f.94 verso. 


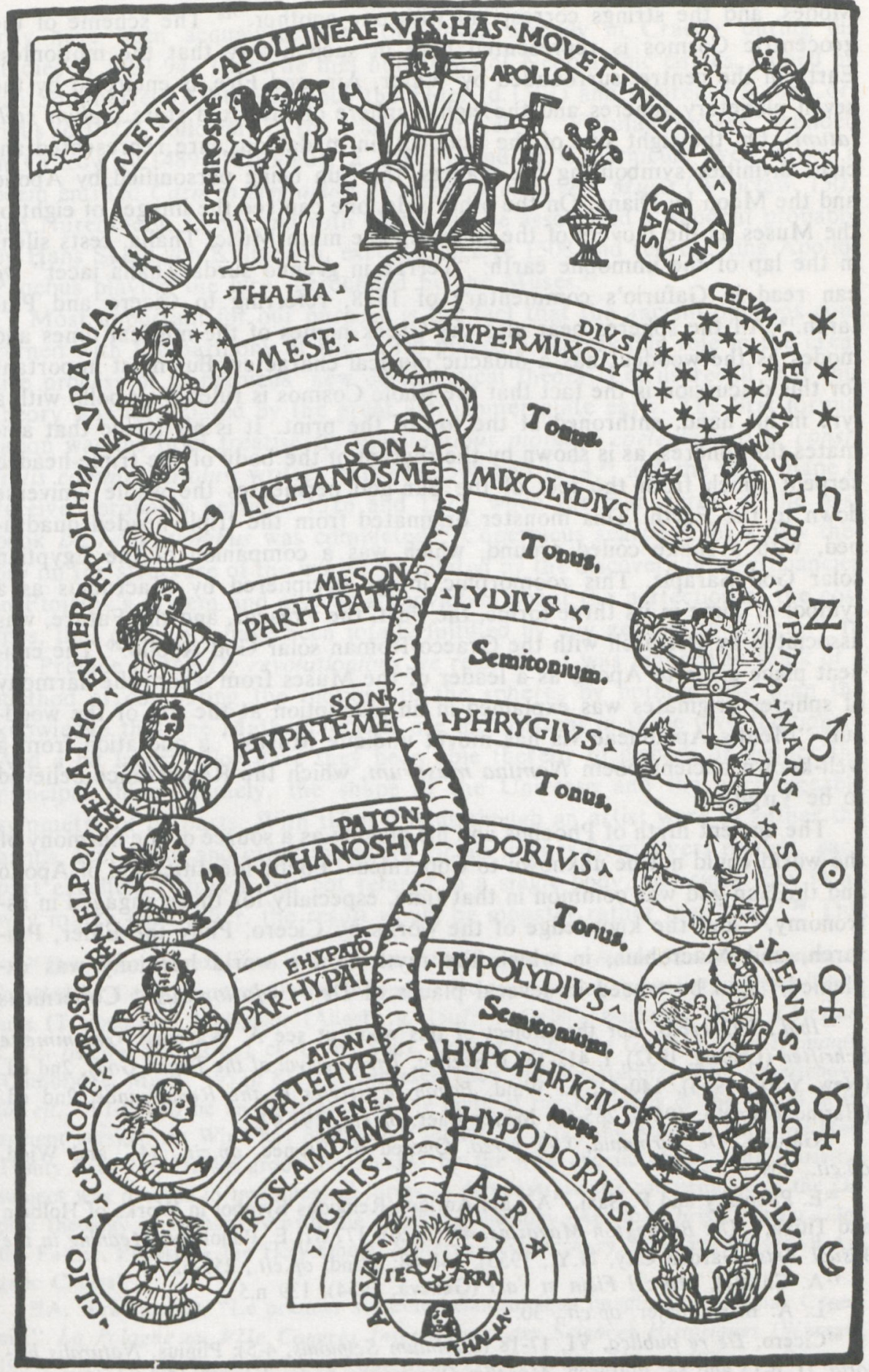

Figure 2. The World Harmony, from Gafurio's Practica musicae (Milan, 1496). Photo W. Wolny. 
Modes, and the strings correspond with one another." ${ }^{18}$ The scheme of the geocentric Cosmos is represented here in such a way that the motionless Earth in the centre, surrounded by Water, Air, and Fire, is encircled by the seven planetary spheres and the eighth sphere of the fixed stars (celum stellatum). On the right side of the woodcut, in medallions, are represented ancient divinities symbolizing the planets, the Sun being personified by Apollo and the Moon by Diana. On the other side, one can see the images of eight of the Muses as the movers of the spheres. The ninth Muse, Thalia, rests silent in the lap of the immobile earth: "Terrae in gremio surda Thalia jacet" we can read in Gafurio's commentary of 1518, referring to Cicero and Plutarch. ${ }^{19}$ All the spheres bear also the Greek names of the musical tones and modes as the woodcut has a didactic musical character. But most important for this discussion is the fact that the whole Cosmos is ruled by Apollo with a lyre in his hand, enthroned at the top of the print. It is his music that animates the spheres, as is shown by the rhythm of the body of the triple-headed serpent which from the feet of the Sun-god permeates the whole Universe down to the Earth. This monster originated from the triple-headed quadruped, with a snake coiled around, which was a companion of the Egyptian solar God Sarapis. This zoomorphic image deciphered by Macrobius as a symbol of Time in its three forms, the Past, the Present, and the Future, was associated by Petrarch with the Graeco-Roman solar God Apollo. ${ }^{20}$ The eminent place given to Apollo as a leader of the Muses from whom the harmony of spheres originates was explained in an inscription at the top of the woodcut: "Mentis Apollineae vis has movet undique Musas," a quotation from a well-known ancient poem Nomina musarum, which the Renaissance believed to be Virgil's. ${ }^{21}$

The ancient myth of Phoebus and his playing as a source of the harmony of the world could not be unknown to Copernicus. Poetic identification of Apollo and the Sun-god was common in that time, especially for those engaged in astronomy, ${ }^{22}$ and the knowledge of the works by Cicero, Pliny the Elder, Plutarch, and Macrobius, in which the myth of the world harmony was explained, ${ }^{23}$ can be traced in several places of De revolutionibus. ${ }^{24}$ Copernicus

${ }^{18}$ Ibid., f.92 recto. For the subject of this woodcut see A. Warburg, Gesammelte Schriften (Leipzig, 1932), I, 412-13; J. Seznec, The Survival of the Pagan Gods, 2nd ed. (New York, 1953), 140-42; E. Wind, Pagan Mysteries in the Renaissance, 2nd ed. (Harmondsworth, 1967), 265-69; Meyer-Baer, op.cit., 191-93.

${ }^{19} \mathrm{Gafurio}$, De harmonia, f.93 verso. Quoted by Seznec, op.cit., 141, and Wind, op.cit., 269.

${ }^{20}$ E. Panofsky and F. Saxl, "A Late-Antique Religious Symbol in Works of Holbein and Titian," The Burlington Magazine, 49 (1926), 177-81; E. Panofsky, Meaning in the Visual Arts (Garden City, N.Y., 1955), 146-68; Wind, op.cit., 259-62.

${ }^{21}$ A. Chastel, Marcel Ficin et l'art (Geneva, 1954), 139 n.5.

${ }^{22}$ L. A. Birkenmajer, op.cit., 30.

${ }^{23}$ Cicero, De re publica, VI, 17-18 (Somnium Scipionis, 4-5); Plinius, Naturalis historia, II, 6-13 and 84; Plutarch, Moralia: Questiones convivales, IX, 13-14, and De animae procreatione in Timaeo, 1029; Macrobius, Commentarii in Somnium Scipionis, II, $2-3$.

${ }^{24}$ A. Birkenmajer, "Commentaries" to Copernicus, De revolutionibus orbium caelestium, I (Warsaw, 1953), 84-90, 95-96, 99, 103, 111-14, 116; L. A. Birkenmajer, op.cit., passim, and Rosen in Three Copernican Treatises, 78, 316. 
may have been acquainted with this myth already in Cracow during his studies in 1491-94. There he met humanists of Neoplatonic circles, guided by Jan Sommerfeld-Aesticampianus the Elder (d.1501) and Laurence Rabe-Corvinus (d.1527), followers of the tradition of Celtis' "Vistulan Society" founded in Cracow (c.1489). Corvinus, a close friend of Copernicus, even wrote a poem entitled Carmen elegiacum de Apolline et novem Musis (Wrocław, 1503 and Nuremberg, 1509); and with Celtis can be associated a woodcut probably by Hans Suess von Kulmbach, executed before 1508 and representing ApolloPhoebus playing the lyre surrounded by the Muses. ${ }^{25}$

Most important for our purpose is the fact that the ancient opinions concerned with the harmony of the world played a remarkable role in the creative process of Copernicus' new cosmological theory. Let us recall that this theory was formulated by the great astronomer quite early. The first formulation was his brief treatise De hypothesibus motuum coelestium a se constitutis commentariolus, written between 1508 and $1514 ;^{26}$ and the final shape it received probably between 1516 and 1525 , when the manuscript of the first book De revolutionibus was completed ${ }^{27}$ Copernicus searched for a new theory on the structure of the world, stimulated by the discovery of discrepancies in Ptolemy's system and also by a conviction about the perfection of the cosmos, that could not have been totally fulfilled by any geocentric system. ${ }^{28}$ In the Preface to the De revolutionibus we read: "... I was induced to think of a method of computing the motions of the spheres by nothing else than the knowledge that the Mathematicians are inconsistent in these investigations." And a bit later: "Nor have they been able thereby to discern or deduce the principal thing-namely, the shape of the Universe and the unchangeable symmetry of its parts. With them it is as though an artist were to gather the hands, feet, head and other members for his images from divers models, each part excellently drawn, but not related to a single body, and since they in no way match each other, the result would be monster rather than man." ${ }^{29}$ This

${ }^{25}$ This woodcut, executed probably ca. 1502 for the Letteraria Sodalitas Danubiana founded by Celtis, ornates a work by one of the members of the society, Petrus Tritonius (Treibenreif), Melopoiae (Augsburg, 1507; in Oglin's workshop ductu Chunradi Celtis feliciter impressae), cf. L. W. Spitz, Conrad Celtis, the German Arch-Humanist (Cambridge, Mass., 1957), 81. The representation was misinterpreted by Ameisenowa (op.cit., 361-63) to be an illustration of the myth of the Harmony of the World in its ancient version. As Wind has pointed out (op.cit., 252-53), the woodcut joins the Holy Trinity with the Deesis group surrounded by the nine angelic choirs. The Christian subject was dressed in mythological forms to demonstrate the concordance of the Orphic theology of humanists with the Christian theology (Apollo $=$ Christ, Jupiter $=$ God the Father, Pegasus $=$ the Holy Ghost, Minerva = Virgin Mary, 9 playing Muses $=9$ Angelic Choirs).

${ }^{26} \mathrm{~A}$. Birkenmajer, "Le premier système héliocentrique imaginé par Nicolas Copernic," La Pologne au VIIe Congrès International des Sciences Historiques (Warsaw, 1933), I, 91-97, and Rosen in Three Copernican Treatises, 339, 343-46, 388.

${ }^{27}$ A. Birkenmajer, "Commentaries," op.cit., 109; Rosen, Three Copernican Treatises, 391-92, and J. Zathey, "The Analysis and History of the Manuscript," Copernicus' Opera omnia, I (Warsaw and London, 1972), 1-23.

${ }^{28}$ A. Birkenmajer, "Commentaries," op. cit., 89 .

${ }^{29}$ Trans. Dobson, ed. cit., 4. Cf. A. Birkenmajer, "Commentaries," op. cit., 102, 115-16. 
opinion of Copernicus in another but equally attractive way was formulated by his pupil, Georg Joachim Rheticus, in De libris revolutionum Nicolai Copernici narratio prima (Gdańsk, 1539), in which, in the name of his master, he criticized all the former astronomers who "... fashioned their theories and devices for correcting the motion of the heavenly bodies with too little regard for the rule which reminds us that the order and motions of the heavenly spheres agree in an absolute system. We fully grant these distinguished men their due honor, as we should. Nevertheless, we should have wished them, in establishing the harmony of the motions, to imitate the musicians who, when one string has either tightened or loosened, with great care and skill regulate and adjust the tones of all the other strings, until all together produce the desired harmony, and no dissonance is heard in any." 30

Copernicus' belief in the harmonious structure of the world was based on a thorough acceptance of "Plato's axiom," that in a perfect Universe all the celestial motions must also be perfect, i.e., circular and uniform. In other words, all the motions of the celestial bodies, as observed from the Earth, should be explained simply as a combination of such perfect motions. ${ }^{31}$ This axiom and the "absurda opinio" of some Pythagoreans, the assumption that the Earth too can be in motion, ${ }^{32}$ became the twofold foundation on which Copernicus built his new cosmological theory.

In Copernicus' aforementioned Preface we read: “... by long and frequent observations I have at last discovered that, if the motions of the rest of the planets be brought into relation with the circulation of the Earth and be reckoned in proportion to the orbit of each planet, not only do their phenomena presently ensue, but the orders and magnitudes of all stars and spheres, nay the heavens themselves, become so bound together that nothing in any part thereof could be moved from its place without producing confusion of all the other parts and of the Universe as a whole." ${ }^{33}$ In the famous tenth chapter of the first book of De revolutionibus, in proud words Copernicus concluded: "So we find underlying this ordination an admirable symmetry in the Universe, and a clear bond of harmony in the motion and magnitude of the orbits such as can be discovered in no other wise." ${ }^{34}$

Rheticus in his Narratio prima suggests that the harmony and perfection of Copernicus' vision of the world is confirmed even by the fact that it reduced the number of moving planetary spheres from seven to six: "Who could have chosen a more suitable and more appropriate number than six? By what number could anyone more easily have persuaded mankind that the whole universe was divided into spheres by God the Author and Creator of the world? For the number six is honored beyond all others in the sacred prophecies of God and by the Pythagoreans and the other philosophers. What is more agreeable to God's handiwork than that first and most perfect number?" 35 The number six

${ }^{30}$ Trans. Rosen, Three Copernican Treatises, 138.

${ }^{31}$ A. Birkenmajer, "Commentaries," op.cit., 89, 102-03.

${ }^{32}$ Idem, "Kopernik jako filozof," Studia i Materiały z Dziejów Nauki Polskiej, n. 7 (1963), 52-53.

${ }^{33}$ Trans. Dobson, ed.cit., 5.

${ }^{34}$ Ibid., 19. Cf. A. Birkenmajer, "Commentaries," op.cit., 102.

${ }^{35}$ Trans. Rosen, Three Copernican Treatises, 147. 
was considered by Pythagoreans as the first perfect number (primus numerus perfectus) and even the most perfect number (numerus perfectissimus) as the first in a set of rare numbers, which are equal to the sum of their integer divisors ( 6 is divided by $1,2,3$, and $1+2+3=6$ ). According to Philo of Alexandria and St. Augustine, often quoted by the humanists, it was for this reason that the number six was privileged by God, who created the world in six days. ${ }^{36}$ Copernicus was at least acquainted with this theory from his reading of Vitruvius and Macrobius; ${ }^{37}$ and, though he did not actually include it in De revolutionibus, yet it does not seem to be a coincidence that he divided his work on the perfect structure of the world into six books. ${ }^{38}$

Alexander Birkenmajer in his "Commentaries" on De revolutionibus stated that the fact that the new vision of the world realizes the postulate of harmony was for Copernicus not only an argument for the superiority of his theory over the old ones but also "... the main-and probably the only oneproof that this theory is the truth, in an ontological sense of this word." 39 In other words "... his own system of the universe and only this one-in Copernicus' thought - represents the truthful, objective state of things, because it is only this system that can introduce order, correctness, and regularity in the universe." ${ }_{40}$

The achievement of this order and regularity by a new system was made possible by its heliocentrism. "Finally we shall place the Sun himself at the centre of the Universe. All this is suggested by the systematic procession of events and the harmony of the whole Universe ..." - we read in one of the chapters of the first book of De revolutionibus." ${ }_{41}$ And the famous passage of the tenth chapter in this book is almost a poetic eulogy of the Sun in the pythagorean-neoplatonic spirit: "In the middle of all (i.e., spheres) sits the Sun enthroned. In this most beautiful temple could we place this luminary in any better position from which he can illuminate the whole at once? He is rightly called the Lamp, the Mind, the Ruler of the Universe; Hermes Trismegistus names him the Visible God, Sophocles' Electra calls him the Allseeing. So the Sun sits as upon a royal throne ruling his children the planets which circle round him." ${ }_{42}$

Therefore the creator of the heliocentric vision of the world had particular

${ }^{36}$ To the texts quoted by me formerly in "Raphael's 'St. Cecilia.' An Iconographical Study," Zeitschrift für Kunstgeschichte, 31 (1968), 7, 21 n. 83, I can now add: Vitruvius, De architectura, III, 1; Macrobius, Commentarii in Somnium Scipionis, I, 6, 13, and Saturnalia, VII, 13, 10; L. B. Alberti, Libri de re aedificatoria decem, IX, 5.

${ }^{37}$ A. Birkenmajer, "Commentaries," op.cit., 84, 90, 111.

${ }^{38}$ Wasiutyński, op.cit., 437. As Rosen has pointed out (Three Copernican Treatises, $147 \mathrm{n} .140$ ) there is no evidence for Copernicus' acceptance of number mysticism in his works.

${ }^{39}$ A. Birkenmajer, "Commentaries," op.cit., 115.

${ }^{40}$ Ibid., loc. cit.

${ }^{41}$ Trans. Dobson, ed.cit., 16. Also Rheticus, Narratio prima, trans. Rosen, Three Copernican Treatises, 139, 143.

${ }^{42}$ Trans. Dobson, ed.cit., 19. Also Commentariolus where Copernicus speaks about the "... ballet of the planets" (Three Copernican Treatises, 90). A. Birkenmajer ("Commentaries," op.cit., 113-14) pointed out that the comparison of the world to a temple, the Sun called a Lamp, a Mind, and a Ruler of the Universe, as well as an 
reasons for taking Apollo playing a lyre-a representation illustrating the ancient myth of Phoebus the Sun-god and his music as the source of the Harmony of the Universe - as a personal emblem. In his theory the sun became, instead of the central planet, the centre of the Universe; and, thus the poetic expression in the aforementioned poem by pseudo-Virgil: "In medio residens complectitur omnia Phoebus," acquired a literal value. At the same time a harmony of sounds, supposed to be produced by the spheres moving under the rule of Apollo's music, became - in his opinion-the real, although not acoustical, harmony of the simple circular spheres, on which the six planets move in a uniform way around the sun. What in the beautiful myth of pagan antiquity, so admired by Copernicus, looked like a presentiment of a truth unknown till then, according to his theory became objective reality, the perfection and beauty of which fascinated its discoverer. ${ }^{43}$

Let us recall the words of the Dutch mathematician Rainer Gemma of Friesland (1508-55) in a letter of 1541: "It seems obvious that Muses in their Fate after leaving the sources of Pegasus wandered to Sarmatia, attracted I don't know what with, the charms of the land or the genius of its inhabitants.... Not to mention others, Urania fixed there her settlements and inspired her new devoted admirers, who brought us the new Earth, new Phoebus, new stars, and even the whole different world." 44 The image on Copernicus' seal, I submit, represents this new Phoebus and the new harmony of the completely changed world.

\section{Polish Academy of Science, Institute of Art History, Warsaw.}

idea of the Sun reigning over the planets Copernicus drew from Cicero (Somnium Scipionis, 4) and Pliny the Elder (Naturalis historia, II, 6, 12-13). Sophocles' "Allseeing Sun" was taken not from Electra but from Oedipus in Kolonos (869) and the Sun was called visibilis deus in Hermes Trismegistus' Poimander, probably known to Copernicus in Ficino's translation (published repeatedly since 1471). For the further discussion on the problem see Rosen, "Copernicus' Quotation from Sophocles," op.cit., 369-79, and idem, "Was Copernicus a Hermetist?" Minnesota Studies in the Philosophy of Science, 5, Historical and Philosophical Perspectives of Science, ed. R. H. Stuewer (Minnesota, 1970), 163-71.

${ }^{43}$ The role of aesthetic theories in Copernicus' scientific thought is a subject of W. Tatarkiewicz's study in Rocznik Krakowski (1973). I am indebted to Prof. Tatarkiewicz for making the text of it available to me. In this matter one should also mention Erwin Panofsky's statements of the links between aesthetic and scientific theories in Galileo: Galileo as a Critic of the Arts (The Hague, 1954); A. Koyré, "Attitude esthétique et pensée scientifique," Critique, 12 (1955), 843-47. Galileo approved Copernicus' system in its original form and ignored the rules of Kepler because they contradicted the ancient belief in the perfection of the sphere, circle, and uniform circular motion. In this way the same ancient theories which stimulated Copernicus to construct the new vision of the world became an obstacle in the improvement of his work.

${ }^{44}$ Quoted from Franz Hipler, Beiträge zur Geschichte des Humanismus (Braunsberg, 1890), 95, and Prowe, op.cit., I-2, 284. 